\title{
Wolfgang Geiger (17 July 1921 - 3 July 2000)
}

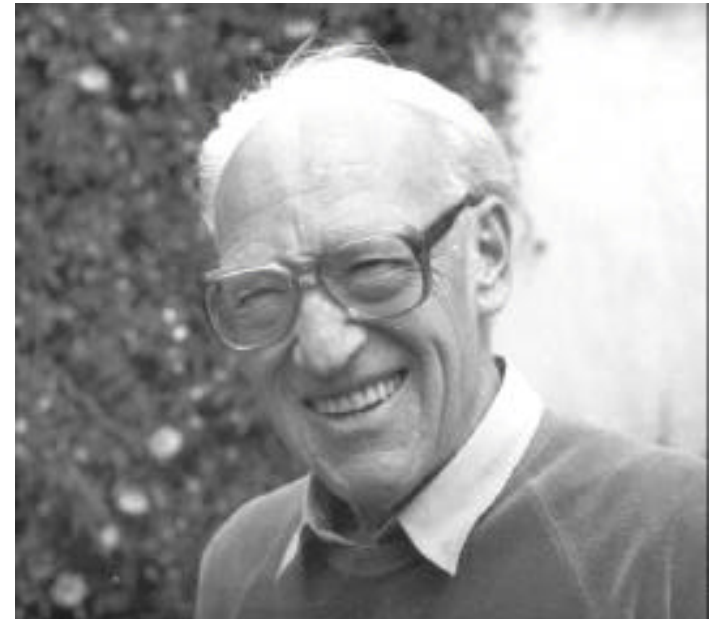

Professor Wolfgang Geiger

Wolfgang Geiger died on the $3^{\text {rd }}$ July 2000, at the age of 79 . He was born on July $17^{\text {th }} 1921$ in Biel; his mother died at his birth. His childhood was spent with his father, a well-known artist, partly in Ligerz, on Lake Biel, and partly in Porto Ronco in Ticino, on Lago Maggiore. After high school in Biel, he began his University studies, first at the Swiss Federal Institute of Technology in Zürich, then in Basel, where he studied under Professor A. Portmann. During his PhD a grant from the Janggen-Pöhn foundation enabled him to work for some months at the Institut des Pêches maritimes du Maroc, in Casablanca, with Dr. J .Furnestin. In 1953 he completed his $\mathrm{PhD}$ on teleost fish brain. His career as a biologist began in Bern at the Eidgenossische Inspektion für Fortwesen, Jagd und Fischerei. In 1962 he was appointed head assistant (chef des travaux) at the University of Geneva, in the comparative anatomy and physiology laboratory (Dr H. J. Huggel), where he discovered the joys and the limitations of teaching. He was highly regarded as a lecturer and taught in a relaxed atmosphere of mutual respect and trust, much appreciated by his students. Professor Geiger was also the main organiser of field trips to Sète, on the French Mediterranean coast, where he was in his element living on the water. He went out on the trawlers with the students and introduced them enthusiastically to the marvels of sea fauna. He was happy during those field trips and had the knack of communicating his happiness to the students.

In Geneva he also continued his research on fish biology. His involvement in fisheries programs was constant, but he was now also beginning to be very interested in the ultrastructure of reproductive organs, and took an active part in the development of the electron microscopy service. His dry sense of humour was in- valuable in coping with the daily problems of the laboratory : an approach he found much more efficient than conflict!

In 1969 he left Geneva to join the Swiss Federal Institute for Water Resources and Water Pollution Control (EAWAG), in Dübendorff (Zürich), and Kastanienbaum (Luzern). There he created the department of biology and fishing science. At that time it was becoming more and more evident that fish health could be regarded as an indicator of water quality, which was deteriorating, mainly because of lake eutrophication. He was called as an expert on many cases of water pollution, including some in Southern Switzerland. A great deal of interest focused on problems connected with fisheries, and many studies were produced. Several students took diplomas or wrote theses under Wolfgang Geiger's direction, on subjects related to the management of fisheries and ichthyopathology. This was the start of a real school, whose students are now active in the various cantonal services for the management of fauna and fisheries.

This period also saw the beginning of a close collaboration with Northern Italy, embodied by the Institute of Hydrobiology of Pallanza (Dr. E. Grimaldi and Dr. G. Giussani), and the Istituto Zooprofilattico of Turin (Dr. P. Ghittino). The problems tackled were those of ulcerative dermal necrosis, viral haemorrhagic septicaemia, disinfection of trout farms, saprolegniosis, branchiomicosis, the taxonomy of coregonus in lakes Thun, Brienz and Biel. In Locarno and Airolo-Pesciüm Professor Geiger took part in the first federal courses in Italian for fishing-wardens.

During his tenure at EAWAG, the word «ecology» was becoming popular, and his main objective was to make fishermen aware of the problems of water pollution and the environment. The death of Wolfgang Geiger deprives us of a man who throughout his life was concerned with the equilibrium between the management and the protection of nature. To meet this challenge successfully demanded his scientific qualifications allied to his great humanity. We have lost a sincere and generous friend. Our profound sympathy goes to his wife, Mariann Geiger.

$$
\begin{gathered}
\text { Raffaele Peduzzi } \\
\text { and } \\
\text { Renata Boucher-Rodoni }
\end{gathered}
$$

Professor at the University of Geneva, Director of the Istituto Batteriosierologico, Lugano

and

Chargé de recherche CNRS, Biologie des Invertébrés marins, MNHN, Paris 